\title{
Building relationship innovation in global collaborative partnerships: big data analytics and traditional organizational powers
}

Pervaiz Akhtar $^{\mathrm{a}}$ (corresponding author), Zaheer Khan ${ }^{\mathrm{b}}$, Rekha Rao-Nicholson ${ }^{\mathrm{c}}$, Minhao Zhang ${ }^{\mathrm{d}}$

${ }^{a}$ Logistics Institute, Hull University Business School, University of Hull

${ }^{\mathrm{b}}$ Kent Business School, University of Kent

${ }^{\mathrm{c}}$ Newcastle University London

${ }^{\mathrm{d}}$ York Management School, University of York

This is the peer reviewed version of the following article: Akhtar, Pervaiz and Khan, Zaheer and Rao-Nicholson, Rekha and Zhang, M (2016) Building relationship innovation in global collaborative partnerships: big data analytics and traditional organizational powers. R\&D Management, which has been published in final form at https://doi.org/10.1111/radm.12253). This article may be used for non-commercial purposes in accordance With Wiley Terms and Conditions for self-archiving. 


\section{Building relationship innovation in global collaborative partnerships: big data analytics and traditional organizational powers}

This study examines how relationship innovation can be developed in global collaborative partnerships (alliances, joint ventures, mergers, and acquisitions). The recently emerging theory of big data analytics linked with traditional organizational powers has attracted a growing interest, but surprisingly little research has been devoted to this important and complex topic. Therefore, after developing the theoretical foundations, our study empirically quantifies the links between the theoretical constructs based on the data collected from chief executive officers, managing directors, and heads of departments who work in contemporary global data-and-information driven collaborative partnerships.

The results from structural equation modeling indicate that the relationship innovation depends on the power of big data analytics and non-mediated powers (expert and referent). The power of big data analytics also mediates the correlation between non-mediated powers and relationship innovation. However, mediated powers (coercive and manipulative) negatively affect the power of big data analytics and relationship innovation. The interaction effects further depict that analytically-powered partnerships have better relationship innovation compared to those which focus less on the analytical power. Consequently, the contributions of this study provide a deeper understanding of mechanisms of how modern collaborative partnerships can use big data analytics and traditional organizational powers to co-create relationship innovation.

Keywords: Relationship innovation; global collaborative partnerships; big data analytics; traditional powers; structural equation modeling; endogeneity 


\section{Introduction}

The theory of big data analytics and data-driven business operations have recently been the focus of several studies (e.g., Akhtar et al., 2015; Wang et al., 2016). Increasing information, analytics, and modern technology for relationship innovation have made these emerging trends pertinent not only for individual consumers but also for global collaborative partnerships such as horizontally and vertically coordinated supply chain networks, alliances, joint ventures, mergers, and acquisitions. Additionally, this research area is plagued with the knowledge gaps that are manifested due to the emerging theories related to big data analytics, particularly in contemporary global collaborative partnerships and relationship innovation (Akhtar et al., 2015; Makri et al., 2010; Maloni \& Brown, 2006). New technologies and processes are persistently explored to mitigate as well as eradicate modern collaborative relationship problems (Ahammad et al., 2016; LaValle et al., 2013), and collaborative partnerships have adopted various value-based and sustainable processes to develop their competitive advantage through the development of relationship innovation, which combines trust building, improving satisfaction, and sharing data and information among collaborative business partners (Akhtar et al., 2015; Pullman et al., 2009).

The appropriate use of the power of big data analytics and traditional organizational powers (mediated powers-coercive and manipulative powers; non-mediated powers-expert and referent powers) can play a key role to build the relationship innovation in such partnerships. Studies on traditional organizational powers often focus on the links between the powers and certain performance dimensions (Maloni \& Benton, 2000; Terpend \& Ashenbaum, 2012) and show that such powers can have opposing effects on the constituents of collaborative partnerships, which need more research (Terpend \& Ashenbaum, 2012). Additionally, contemporary global collaborative partnerships have begun to actively engage in big data analytics (i.e., analytics produced from structured and unstructured data) to improve their relationship innovation with other involved business partners and customers (McAfee \& Brynjolfsson, 2012). However, the power of big data analytics and the links with relationship innovation (trust building, creating satisfaction, sharing 
data, information and analytics) are not clear because the powers of big data analytics and related technologies have only recently emerged. Further, the links between traditional organizational powers and the power of big data analytics have not been explored yet, although some researchers have claimed that big data users can be $5 \%$ more productive and $6 \%$ more profitable than their competitors (Waller \& Fawcett, 2013). Such claims need more support, and the dearth of theoretical and empirical studies on exploring these links is the key reason to conduct this study.

In summary, this study offers the following contributions by investigating the unexplored positive and negative effects of underlying constructs (mediated powers, non-mediated powers, and powers of big data analytics) on relationship innovation in global collaborative partnerships. Theoretically, the study presents the literature review on the links between traditional organizational powers, big data analytics, and relationship innovation, which lead to the development of the conceptual framework and hypotheses. Empirically, a rich dataset was collected from different top management representatives (i.e., chief executive officers, managing directors and heads of departments), working in collaborative partnerships that apply big data analytics in their operations. This ensures the reliability and relevance of our dataset on which the theoretical framework was established and the hypotheses were tested. Methodologically, this study also takes possible steps to deal with endogeneity issues that have largely been ignored by many non-experimental studies (Akhtar et al., 2015; Antonakis et al., 2010). The implications raised from this study are also discussed.

\section{Background review and knowledge gap}

Mediated organizational powers include coercion and manipulative powers. The coercion power is defined as a dominant business partner's ability to apply punishments to other collaborative partners. In manipulative powers, a dominant partner can exert influence on other partners through manipulations in which targeted partners can experience negative feelings and lose their autonomy. As a result, this approach can damage the relationships between collaborating business partners and also hinders them to apply innovative practices to build better business relationship networks 
(Terpend \& Ashenbaum, 2012). Non-mediated powers (expert and referent) refer to the sources of power which guide business partners and also help them in decision-making. Using expert powers, business partners value knowledge or expertise of a firm and are willing to engage with other business partners due to the importance of their knowledge. The referent power is a power of a business partner over other collaborating partners based on a high level of identification, admiration and respect that help to build enduring innovative relationships among them (Puranam et al., 2006; Terpend \& Ashenbaum, 2012).

The power of big data analytics is based on how frequently collaborative partners use structured (e.g., large volume of data consisting of numbers) and unstructured (e.g., text data) data. Processing such data to produce information and analytics is called big data analytics, which are used to build relationship innovation (Chen et al., 2012; McAfee \& Brynjolfsson, 2012). There is no single agreed definition of innovation; it can either be an incremental change or a radical change in processes and products. Our definition of relationship innovation is more relevant to the former change that encompasses multiple dimensions (e.g., trust, satisfaction, information, data, and analytics) to build innovative relationship among collaborative partners (Aramyan et al., 2007; Lin et al., 2010; Nyaga et al., 2010; Ollila \& Yström, 2016).

The important role of powers and their effects have been acknowledged; business partners' satisfaction (Benton \& Maloni, 2005), discontinuous innovation (Phillips et al., 2006), business network profitability (Chen et al., 2014), collaborative partnership effectiveness (Xue et al., 2014), knowledge sharing (Chen et al., 2015), buyer-supplier relationship commitment (Clauss \& Spieth, 2016), data, information, and analytics (Akhtar et al., 2015; Ollila \& Yström, 2016). Organizational powers are often seen as the mechanism to get desired outcomes from other business partners either through reward, punishments or sanctions (Benton \& Maloni, 2005) that could have strong implications, posing challenges for managers to build innovative relationships in collaborative partnerships (Ollila \& Yström, 2016). 
The types of power can also have opposing effects. For instance, if a collaborative partner uses meditated powers, this could create conflicts and loss of trust that can harm business relationships, leading to negative feelings toward cooperation, whereas business partners exercising non-mediated power could results in positive attitude towards cooperation and facilitating trust, satisfaction, data, analytics and information sharing, leading towards relationship innovation (Nyaga et al., 2010; Phillips et al., 2006; Terpend \& Ashenbaum, 2012). In selected global collaborative partnerships, business partners may use both mediated and non-mediated powers to enhance their relationship innovation linking with small farmers, producers and growers. However, there is no research in this area, which leads towards an elusive condition.

Additionally, along with these traditional organizational powers (mediated and non-mediated), the recently emerged power of big data analytics is also influencing relationship innovation. This is due to the potential powers, analytics, data and information sharing that keep collaborative partners connected and united to build innovative relationships in their business networks. For example, McAfee and Brynjolfsson (2012, pp. 64) noted that "the more companies characterized themselves as data-driven, the better they performed on objective measures of financial and operational results ... companies in the top third of their industry in the use of data-driven decision making were on average, $5 \%$ more productive and $6 \%$ more profitable than their competitors". Such top-performing companies use five times more data analytics than low-performing companies, indicating a potential link of the power of big data analytics with relationship innovation (Akhtar et al., 2015; LaValle et al., 2013), which has not been explored empirically yet and this study seems the first to explore the link.

On the other hand, research also finds that not all big data initiatives are successful as companies lack skills that are necessary for taking advantage of big data analytics (Waller \& Fawcett, 2013). Similarly, Barton and Court (2012, pp. 81) indicated the potential value of the power of big data analytics in the following way: advanced analytics is likely to become a decisive competitive asset in many industries and a core element in companies' efforts to improve their network relationships. 
To the best of our knowledge, the influence of mediated and non-mediated powers and their links with relationship innovation, particularly with the power of big data analytics (a new source of power in contemporary global collaborative partnerships), have not been addressed (Akhtar et al., 2015; Ollila \& Yström, 2016; Waller \& Fawcett, 2013). Additionally, the combined effects of powers (coercive + manipulative; expert + referent) have not been investigated together along with the power of big data analytics and relationship innovation. Thus, this study provides important contributions in this regard.

\section{Framework and hypotheses development}

\subsection{Mediated powers (coercive, manipulative), power of big data analytics, and relationship innovation}

Contemporary global collaborative partnerships are greatly reliant upon big data analytics to generate visibility in their operations as well as to observe market trends linked with inventory management (Hazen et al., 2014). Also, the mediated powers can leverage the power of analytics to control and manage modern data-dependent operations (Hazen et al., 2014). The efficient and effective use of data analytics can counteract against the mediated powers generally used in modern collaborative operations (Blackhurst et al., 2011). McAfee and Brynjolfsson (2012) also mentioned that data-driven decision making can significantly improve relationship innovation. Moreover, the power of big analytics can significantly influence the way the several collaborative operations are managed. For example, firms can identify sales patterns and customers' behavior that can help in accurate forecasting and joint inventory management that help in building innovative relationships among global collaborative partnerships (Clauss \& Spieth, 2016; Waller \& Fawcett, 2013).

The applications of big data analytics can be especially pertinent to global partnerships. The power of big analytics promotes efficiency within global firms, principally by using analytical approaches to provide key decision-making knowledge and accurate forecasting that lessen operating expenses (Hedgebeth, 2007). Global firms with more mature analytics, with a greater power of analytics within their collaborative systems, reduce their costs faster and make higher 
profit than their competitors with less mature analytics (Hoole, 2005). These factors contribute to trust building that is an important component of innovative relationship management (Bidault \& Castello, 2009).

Traditional organizational powers such as coercive (e.g. punishment for not aligning collaborative operations) and manipulative (e.g. misusing data and information) can have negative effects on the power of big data analytics because such mediated powers hinder analytical practices shared among collaborative partnerships. However, not enough empirical studies are available to confirm these links (Akhtar et al., 2015; Waller \& Fawcett, 2013).

The key collaborative partners possess a greater ability to sway other constituents of network partners (e.g., food processers, small farmers, and packers) and can potentially exert better control over their suppliers by effectively using data and information (Narasimhan et al., 2009). Their mediated powers are viewed as essential tools to get preferred results from other collaborative partners. This result can be generated through punishments, rewards or sanctions (Ireland \& Webb, 2007), which can have strong implications as well as pose challenges for building innovative relationships.

On one hand, it can lead to credible and widespread use of innovative practices within certain industries. For example, in the case of forestry industry, key customers like the construction firms and furniture companies work with supplier firms to improve the certification standards and to adapt more innovating timber harvesting practices (Sharma \& Henriques, 2005). Similarly, the firm size that is closely linked to the traditional organizational power is crucial for earlier phases of innovative relationship management (Sharma \& Henriques, 2005).

Yet, on the other hand, the firms with mediated powers in their collaborative partnerships can create pressures on smaller and weaker network partners to relax the innovative practices for minor economic gains. For examples, firms that contract manufacturing activities in the developing countries might not necessarily demand higher levels of innovative practices observed in their home country, as the targeted partners in developing country have limited sources for innovation 
(Frooman, 1999; Terpend \& Ashenbaum, 2012). In global agri-food collaborative partnerships that are linked with developed and developing countries (Akhtar et al., 2015), traditional powers have been fragmented and they can have different effects on relationship innovation (Akhtar, 2013; Nicolopoulou et al., 2016). Also, the mediated power can reduce trust and satisfaction between collaborative partners, hindering innovative practices (Tachizawa \& Wong, 2015). We thus hypothesize that:

H1: Mediated powers (coercive, manipulative) will have a negative effect on the power of big data analytics in collaborative partnerships.

H2: Mediated powers (coercive, manipulative) will have a negative effect on relationship innovation in collaborative partnerships.

\subsection{Non-mediated powers (expert, referent), power of big data analytics, and relationship} innovation

Expert and referent powers encourage building innovative relationships and sharing expertise that can push the power of big data analytics to be used frequently. The power of analytics can also improve service quality by using analytical insights raised from customer reviews, which depend on the use of non-mediating powers. The power of big data analytics is also important for collaborative partners to engage and cooperate on enhancing expert and referent powers. Thus, it is important for dominant partners to use their influence to encourage the adoption and implementation of big data analytics among their partners (Akhtar et al., 2015; Ke et al., 2009; Terpend \& Ashenbaum, 2012).

The non-mediated powers can also guide collaborative partners' behavior and decision making activities through analytics that develop the pathways to success. The dynamics of referent power imply that collaborative partners identify themselves with a dominant firm in a hope to be closely involved and use big data analytics (Akhtar et al., 2015; Terpend \& Ashenbaum, 2012). In case of the expert power dynamics, the collaborative partners value the knowledge or expertise of a dominant firm and are willing to engage with the firm due to the importance of analytical knowledge that helps them to apply such knowledge for better relationship building (Akhtar et al., 
2015; Terpend \& Ashenbaum, 2012). The non-mediated powers further create the culture of big data analytics that fosters knowledge-sharing, understanding and expertise to implement big data analytics among collaborators and network partners, thus impacting innovative practices for relationship building. Considering the above arguments, it can be posited that non-mediated powers (expert, referent) will affect the power of big data analytics, thus:

H3: Non-mediated powers (expert, referent) will have a positive effect on the power of big data analytics in collaborative partnerships.

The non-mediated powers can also transcend the trust-barriers and encourage collaborative partners to engage in data collecting, analytics and information sharing that mainly contribute to relationship innovation among network partners. Firms with expert or referent powers in their collaborative networks encourage others to use similar processes for achieving relationship management (Brown et al., 1996; Clauss \& Spieth, 2016; Terpend \& Ashenbaum, 2012). For example, information and expertise are constantly feed-backed into the monitoring systems used to strengthen collaborative partnerships. This significantly improves service quality, product quality, environment aspects and relationships among collaborative partners, contributing to relationship innovation (Brown et al., 1996; Frey et al., 2013; Terpend \& Ashenbaum, 2012). Thus, firms using non-mediated powers (expert and referent) will drive positive influence on the collaborative partners' trust and cooperation, which are the key factors for innovative relationship building (Bidault \& Castello, 2009).

Overall, this development of trust, satisfaction and cooperation between collaborative partnerships will lead to the wider dissemination of innovative practices and we would expect better innovative relationship among business partners (Akhtar et al., 2015). Hence, we propose two hypotheses; a) one is for the links based on the above arguments, b) the other based on the overall arguments discussed from $\mathrm{H} 1$ to $\mathrm{H} 4$, which is a sub-hypothesis (H5). Figure1 represents our hypotheses and the interrelationships among the underlying constructs. 
H4: Non-mediated powers (expert, referent) will have a positive effect on relationship innovation in collaborative partnerships.

H5: The power of big data analytics mediates the relationship between traditional organizational powers and relationship innovation in collaborative partnerships.

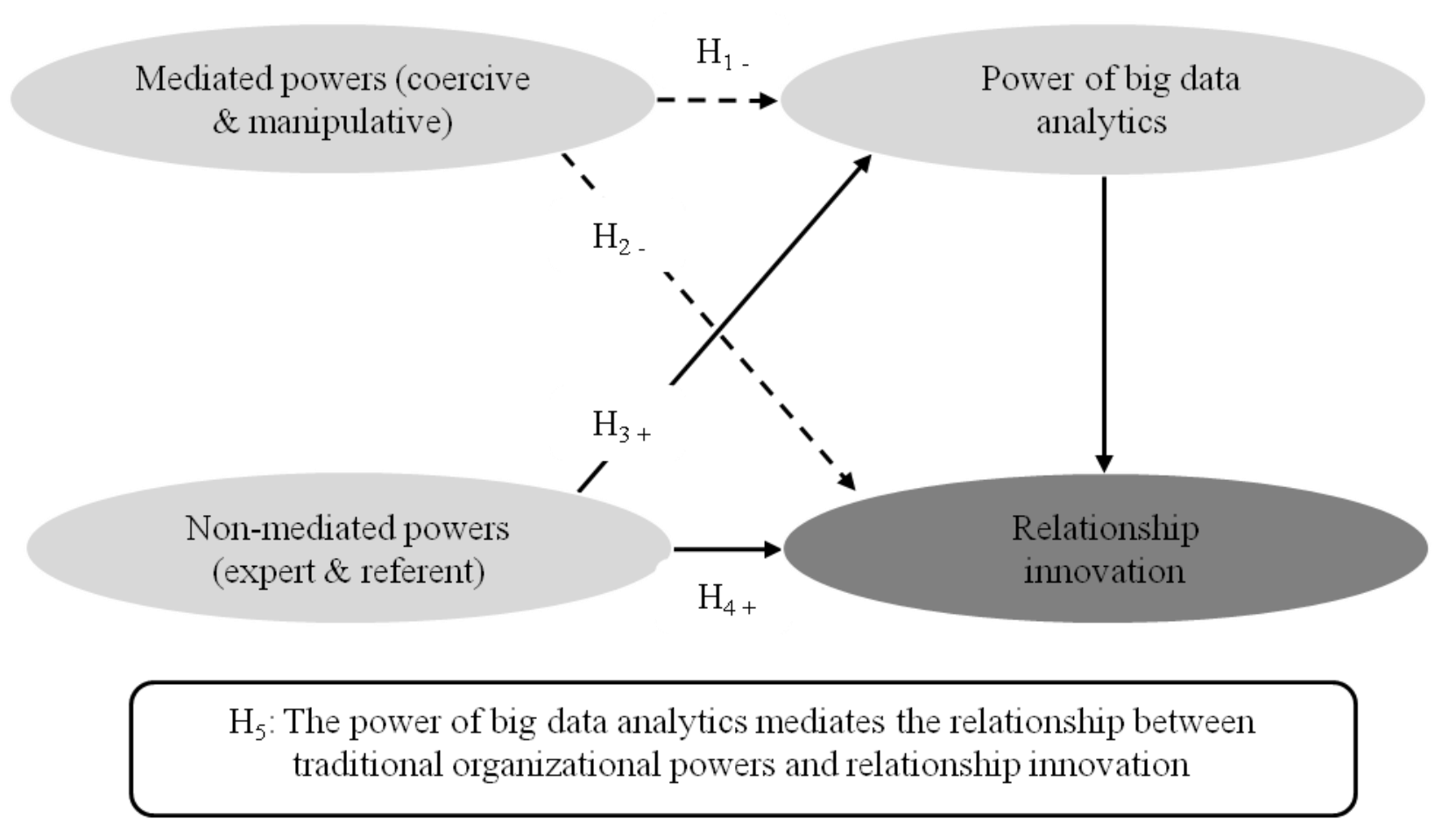

Figure 1. Theoretical framework and proposed hypotheses.

\section{Context and Methodology}

\subsection{Global collaborative partnerships}

The term global collaborative partnership has been used to describe business partnerships that are globally connected (e.g., Europe, USA, Middle East and Asia) (Akhtar et al., 2015). These partnerships consist of a network of business partners working together to perform different activities and processes in order to bring different products and services to the end market to satisfy customers' needs and demands (Christopher, 2005). However, global collaborative partnerships (horizontally and vertically coordinated supply chain networks, alliances, joint ventures, mergers, and acquisitions) are inherently more complex as they have different legal, business and cultural systems (Zhu et al., 2008). These factors make such partnerships more complicated and difficult to manage than traditional business partnerships. The changing consumers' attitude, data-inundated 
global business operations and contemporary distribution practices need an innovation-based relationship approach in which collaborative partners jointly can use emerging technology, big data, complex information, analytics and traditional organizational powers for better performance (Akhtar et al., 2015; Puranam et al., 2006; Terpend \& Ashenbaum, 2012).

\subsection{Sample and measurement scales}

The sample consists of the selected global collaborative partnerships of dairy, meat, vegetables, and fruits. These firms have main headquarters in the UK and New Zealand but are connected globally (USA, Europe, Australia, China, Malaysia, Thailand, Saudi Arabia, UAE, India, Bangladesh, Sri Lanka, and Pakistan) through their import and export operations. We did select these partnerships not only because of the knowledge gap in the domain but also due to the nature of their global operations that largely depend on contemporary big data, analytics and information that keep them connected globally, this helped us to integrate a newly emerged power, called the power of big data analytics contributing to relationship innovation. Additionally, the selected products/produce play a vital role, particularly in agriculture economies. For example, New Zealand dairy contributes about $35 \%$ to total global dairy trade and exports $95 \%$ of the entire dairy produce in the country (Schewe, 2011). The country also provides more than $40 \%$ of total global lamb exports in the world (Ledgard et al., 2011).

From the selected chains, chief executive officers, managing directors, and heads of departments were found suitable participants due to their knowledge about the topic. A total of 1275 members were invited. After excluding incomplete responses, 232 (18\% response rate) responses were used to execute structural equation modeling with parceling as the strategy recommended by methodologists (e.g. Kline, 2011). The sample characteristics are provided in Table 1. 
Table 1. Sample characteristics

\begin{tabular}{llrr}
\hline Characteristics & & No & $\%$ \\
\hline Job titles & Heads of departments & 100 & 43 \\
& Directors & 99 & 43 \\
& CEOs & 33 & 14 \\
Agrifood networks & Veg. \& fruits & 111 & 48 \\
& Meat & 82 & 35 \\
& Dairy & 39 & 17 \\
Employees & $<20$ & 68 & 29 \\
& $20-100$ & 92 & 40 \\
& $101-200$ & 72 & 31 \\
Turnover $(\$ \mathrm{~m})$ & $<15$ & 40 & 17 \\
& $15-60$ & 192 & 83 \\
Total & & 232 & 100 \\
\hline
\end{tabular}

The items for the constructs related to mediated powers and non-mediated powers were based on well-established research (Bidault \& Castello, 2009; Terpend \& Ashenbaum, 2012). However, to the best of our knowledge to date, there are no items (questions) available to measure the power of big data analytics affecting relationship innovation. The relevant literature from other fields (e.g. Chen et al., 2012) fortunately guided us to ask relevant questions to develop construct for the power of big data analytics, which were later refined by using exploratory factor analysis (EFA). The EFA with varimax rotations, eigenvalues $\geq 1$ and scree plots assisted to develop the constructs. Relationship innovation is consisted of three dimensions: 1) trust; 2) data, analytics, and information sharing and 3) satisfaction. Though we utilized EFA to further develop them, these items were taken from well-established research and modified according to the content of this study (Nyaga et al., 2010; Patnayakuni et al., 2006). All measurement scales utilized a 5-point Likert scale and the brief description of the scales is provided in Appendix.

\subsection{Biases and endogeneity}

The chi-square difference tests showed no difference between the respondents and nonrespondents/early to late respondents. Research shows that majority (more than 65\%) of papers 
published in selected journals have not adequately addressed endogeneity. Endogeneity mainly includes common-method variance, measurement errors, omitted variables, and simultaneity (Antonakis et al., 2010), which we have addressed as follows.

For common-method variance (CMV), theoretically, extant research and EFA were utilized to develop the constructs. Also, unfamiliar words, double-barreled questions and technical words were avoided. The items were further grouped with different construct items (not in conceptual dimensions). The extensive use of negatively-worded items was also avoided because they could distrust participants' pattern of responding, creating a source of method bias, as stated by (Podsakoff et al., 2003). The anonymity of our survey was maintained and a single-informant bias was avoided by collecting data from multiple informants. Statistically, Harman's one-factor test produced multiple factors explaining greater variance compared to a single factor solution or combinations. Additionally, the marker variable technique (the variable was the number of languages research participants knew) with small correlations provided a reasonable proxy. The latent factor approach also did not show that CMV bias was an issue.

Although structural equation modeling (e.g., maximum likelihood estimate) corrects for random measurement errors, researchers still need to control for the measurement errors if they use a single indicator approach. However, we applied a multiple indicator approach, thus, the correction was not required. Omitted bias exists when researchers test the validity of a construct without including important variables/constructs. This study uses multiple constructs, which further consist of subconstructs (the detail is given in Appendix). The problem of simultaneity (reverse causality) occurs when two variables simultaneously affect/cause each other and have reciprocal feedback loops (e.g. Antonakis et al., 2010). This problem was addressed using the literature and logical arguments that reflect employees' practices linked with business outcomes. 


\section{Results}

This study applies a two-stage structural equation modeling to validate the constructs and to test the hypotheses (e.g. Kline, 2011). First, various quality checks (EFA, building measurement models, items reliability, composite reliability, convergent validity and discriminant validity) were conducted, which are listed in Table 2 and Table 3. During the quality checks, one item (PBDA1) was excluded because of low loadings. Second, the hypotheses were tested by scrutinizing the structural relationships between the constructs.

Table 2. Evaluation of measurement models (reliability and validity)

\begin{tabular}{|c|c|c|c|c|c|}
\hline Constructs & Items & $\alpha$ & $\lambda$ & AVE & C.R \\
\hline \multirow{3}{*}{ Mediated powers (MP) } & & 0.75 & & 0.61 & 0.76 \\
\hline & COR & & 0.68 & & \\
\hline & MAN & & 0.87 & & \\
\hline \multirow[t]{3}{*}{ Non-mediated powers (NMP) } & & 0.82 & & 0.70 & 0.82 \\
\hline & EXP & & 0.90 & & \\
\hline & REF & & 0.77 & & \\
\hline \multirow{10}{*}{$\begin{array}{l}\text { Power of Big Data Analytics } \\
\text { (PBDA): }\end{array}$} & & 0.95 & & 0.74 & 0.95 \\
\hline & PBDA $1^{\mathrm{a}}$ & & & & \\
\hline & PBDA2 & & 0.84 & & \\
\hline & PBDA3 & & 0.87 & & \\
\hline & PBDA4 & & 0.82 & & \\
\hline & PBDA5 & & 0.87 & & \\
\hline & PBDA6 & & 0.87 & & \\
\hline & PBDA7 & & 0.92 & & \\
\hline & PBDA8 & & 0.84 & & \\
\hline & & 0.81 & & 0.61 & 0.83 \\
\hline \multirow[t]{3}{*}{ Relationship innovation (RI) } & TRT & & 0.72 & & \\
\hline & DAIS & & 0.86 & & \\
\hline & SAT & & 0.76 & & \\
\hline
\end{tabular}

${ }^{a}$ deleted because of low loading; $\alpha=$ items reliability; $\lambda=$ loadings; AVE =average variance explained; C.R =construct reliability

This study checks discriminant validity of the constructs using two methods. First, the correlation between the constructs was less than the value of 0.85 (Kline, 2011). The values ranged between -0.08 and 0.55 . Second, as calculated in Table 3, the square of the correlation $\left(\phi^{2}\right)$ by each pair of constructs was less than the average variance explained (AVE) (Sekaran, 2000). 
Table 3. Second method for discriminant validity

\begin{tabular}{lllll}
\hline Constructs & $\phi$ & ${ }^{\mathrm{a}} \phi^{2}$ & ${ }^{\mathrm{b}} \mathrm{AVE}$ & $\phi^{2}<$ AVE (condition met) \\
\hline MP \& NMP & -0.08 & $0.01^{\mathrm{a}}$ & $0.66^{\mathrm{b}}$ & Yes \\
MP \& PBDA & -0.23 & 0.05 & 0.68 & Yes \\
MP \& RI & -0.25 & 0.06 & 0.61 & Yes \\
NMP \& PBDA & 0.29 & 0.08 & 0.72 & Yes \\
NMP \& RI & 0.36 & 0.13 & 0.66 & Yes \\
PBDA \& RI & 0.55 & 0.30 & 0.68 & Yes \\
\hline
\end{tabular}

$\phi=$ correlation between constructs, ${ }^{\mathrm{a}} \phi^{2},(-0.08) *(-0.08)=0.01$ (rounded to two digits); ${ }^{\mathrm{b}} \mathrm{AVE}$, $(0.61+0.70) / 2=0.66($ AVE for MP \& NMP)

Figure 2 depicts hypothesis results (standardized) and $R^{2}$ values. $\mathrm{H} 1$ and $\mathrm{H} 2$ propose that mediated powers (coercive, manipulative) will have negative effects on the power of big data analytics and relationship innovation respectively. The results show significant negative effects at $p$ $<0.01$. H3 (non-mediated powers to the power of big data analytics) and H4 (non-mediated powers to relationship innovation) are positive and highly significant. Additionally, the fit indices $\left[\chi^{2} / d f=\right.$ 2.22; $C F I=0.96 ; T L I=0.95 ; I F I=0.96 ; R M S E A=0.07]$ are also greater than $0.90($ Kline, 2011$)$.

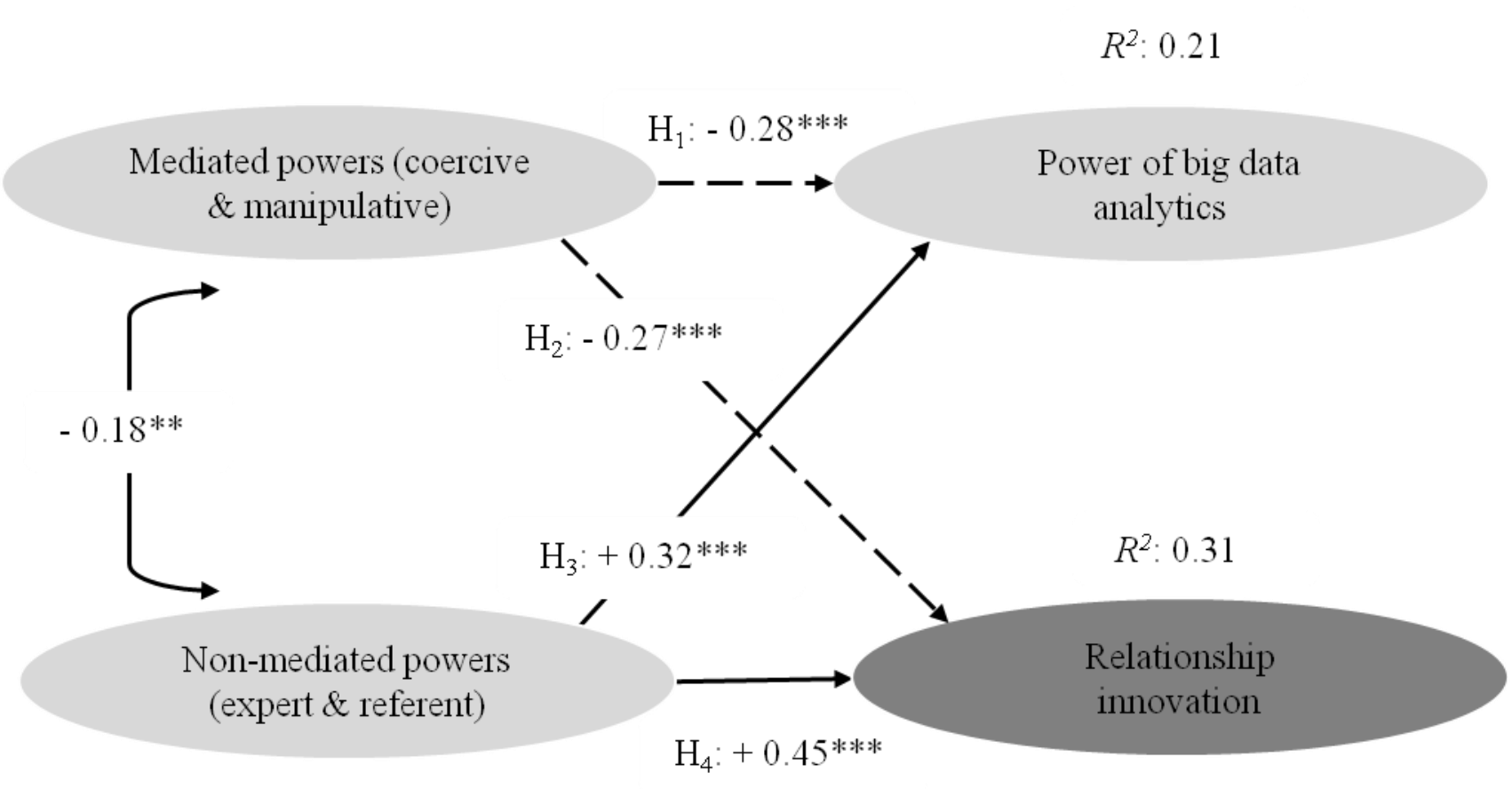

Figure 2. Hypothesis results and $R^{2}$ values 
To test H5 [the power of big data analytics also mediate the relationship between traditional powers (i.e., non-mediated powers, NMP) and relationship innovation], mediating analysis were conducted by applying three approaches: a) causal-steps approach (Baron \& Kenny, 1986), b) Sobel typed-tests (Sobel, 1982) and c) Bootstrapping (Preacher \& Hayes, 2008). The causal-steps approach tested that the independent variable (NMP) affects dependent variable (relationship innovation, RI) with $\beta=0.36$ and $p<0.001$. The independent variable also affects mediating variable (PBDA, power of big data analytics), as $\beta=0.29$ and $p<0.001$. The mediating variable (PBDA) also has a significant relationship with RI $(\beta=0.55$ and $p<0.001)$. Finally, when the model was controlled for the mediating variable, the previous relationship (i.e., between NMP and RI) reduced $(\beta=0.22$ and $p<0.001)$. The results thus showed partial mediation as the relationship was still significant. The Sobel test also depicted that the indirect effect of NMP on RI via PBDA is significantly different from zero at $p<0.001$. Additionally, the Aroian and Goodman tests showed the same outcome.

The bootstrapping method with 5000 samples and 95\% confidence interval was also used (Preacher \& Hayes, 2008). First, NMP was positively associated with RI $[(\beta=0.29, \mathrm{t}(230 \mathrm{df})=$ 5.87, $p<0.001)]$. NMP was positively related to BPDA $[(\beta=0.29, \mathrm{t}(230 \mathrm{df})=4.50, p<0.001)]$ as well. Lastly, the results indicated that the mediator, PBDA, was positively associated with $\mathrm{RI}[(\beta=$ $0.39, \mathrm{t}(230 \mathrm{df})=8.72, p<0.001)]$. Then, the results indicated that the direct effect of NMP on RI reduced $[(\beta=0.18, \mathrm{t}(230 \mathrm{df})=4.00, p<0.001)]$ when controlling for PBDA, thus, suggested partial mediation. Also, the indirect effects of NMP on RI $(\beta=0.11)$ showed the confidence interval between 0.05 and 0.19 .

\section{Discussion and Conclusions}

The overarching aim of this study is to examine the role of traditional organizational powers (both mediated and non-mediated) and the power of big data analytics, impacting relationship innovation in collaborative partnerships. It is clear that existing research has generally been confined to traditional organizational powers. Additionally, many studies of collaborative partnerships have not 
adequately addressed the endogeneity issues. In contrast to existing studies, we examine how relationship innovation can be built by using both mediated and non-mediated powers and the power of big data analytics. Especially, this research contributes to the selected global collaborative partnerships, which are inundated with big data analytics assisting to understand relationship innovation and its components.

\subsection{Theoretical implications}

The findings of this study are not only consistent with extant studies examining the influence of both mediated and non-mediated powers in buyer-supplier relationship exchanges (Benton \& Maloni, 2005; Maloni \& Benton, 2000; Clauss \& Spieth, 2016; Terpend \& Ashenbaum, 2012) but also offer new empirical insights on the associations of mediated, non-mediated sources of organizational powers and big data analytics linked with relationship innovation in collaborative partnerships (Akhtar et al., 2015; Terpend \& Ashenbaum, 2012). The results indicate that collaborative partners that exercise mediated powers (i.e., coercive and manipulative) will have a negative effect on building relationship innovation in collaborative partnerships. This is in line with the studies that have documented mixed results from positive, neutral to even negative effects in collaborative partnerships (Benton \& Maloni, 2005).

As such collaborative partners use this form of power to influence the behavior of other partners in relationship building, thus, it negatively influences developing trust, satisfaction and relationship innovation. Whereas, collaborative partners that rely on non-mediated sources of organizational powers positively influence relationship innovations in collaborative partnerships. This is because of information sharing, use of data and knowledge that enable trust and satisfaction in partnerships (Benton \& Maloni, 2005; Clauss \& Spieth, 2016; Terpend \& Ashenbaum, 2012). These findings further support the view of Handley and Benton (2012) suggesting that when buyers have a dependent relationship with their exchange suppliers they will rely more on non-mediated use of powers instead of solely focusing on mediated powers. 
Also, one of the intuitive findings of this study is the role played by the power of big data analytics on relationship innovation in collaborative partnerships. Specifically, the findings highlight the mediated role of big data analytics between traditional sources of organizational powers and their impact on relationship innovation in collaborative partnerships (Akhtar et al., 2015).

This study also contributes to the scholarly debate on innovation, research and development (R\&D) and partnership learning in the following ways. First, we bring traditional sources of organizational powers (mediated and non-mediated) and big data analytics together in explicating their roles in relationship innovation in collaborative-working environments. Traditionally, organizations have focused on investing resources in-house $R \& D$ as well as exploring outside sources for innovation such as R\&D alliances. Such research has often produced conflicting results positive (Ahuja, 2000; Keil et al., 2008) and negative (Hagedoorn et al., 2003; Weck \& Blomquist, 2008). Our study extends this line of enquiry by demonstrating the value of big data analytics and traditional organizational powers in relationship innovation.

Second, we firmly bring big data analytics into the domains of innovation as well as collaborative partnerships such as alliances, joint ventures, mergers and acquisitions, as there is a lack of research that discusses how big data analytics interact with traditional sources of powers and their respective impacts on relationship innovation. Third, this study advances the theories of learning collaborative partnerships and innovation by focusing on relationship innovation.

Last, it suggests a novel approach to partnerships and innovation, according to which big data analytics can also be operationalized as a mediating variable that determines the relationship between traditional organizational powers (non-mediated power rather than mediated power) and relationship innovation. In particular, understanding emerging concepts such as big data analytics and differentiating different sources of powers can contribute significantly to explain how these variables interact to improve relationship innovation instead of merely focusing on governance mechanisms of powers (Maloni \& Benton, 2000; Terpend \& Ashenbaum, 2012) 


\subsection{Managerial implications}

To further investigate practical implications of the relationship between non-mediated powers (NMP), powers of big data analytics, and relationship innovation, the surveyed partnerships were divided into high or low users of big data analytics. The t-test depicted that the grouping is significantly different (at $p<0.00$ ). The results in Figure 3 show that better relationship innovation is achieved when collaborative firms apply more non-mediated powers and the power of big data analytics. It is thus worthwhile to take this on board that non-mediated and big data orientedpartnerships can better co-create relationship innovation, compared to those which focus on mediated powers and ignore the power of big data analytics linked with non-mediated powers.

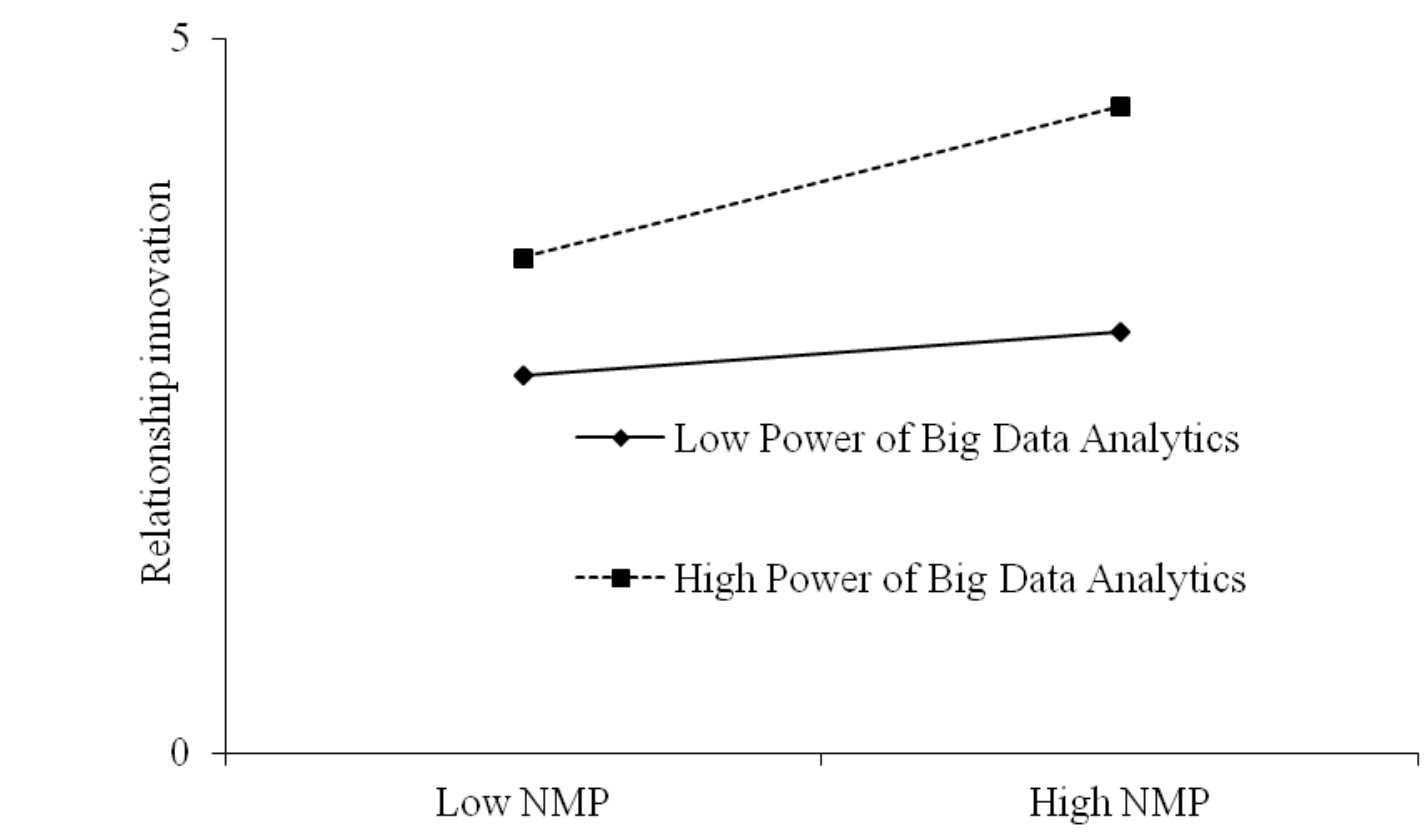

Figure 3. Interaction effects of NMP and PBDA on relationship innovation

Collaborative partners can also establish innovative relationships by building trust in and satisfaction with others (item-level discussion). Similarly, NMP and the power of big data analytics contribute to share data, analytics and information that are the key components to build innovative relationships. On the other hand, mediated powers (coercive and manipulative) are negatively associated with relationship innovation and the power of big data analytics. Consequently, 
collaborative partnerships typified with such powers cannot reap the full benefits of big data analytics, as such powers hinder analytical and innovative practices.

\subsection{Academic implications}

The power of big data analytics does not only have industrial implications, the academic growth in MSc programs in big data analytics has also increased noticeably. For instance, MS analytical programs in the US business schools went up from 5\% in 2011 to more than $75 \%$ in 2015 (Schoenherr and Speier-Pero, 2015). Similar developments are taking place in Europe and other developed areas. In this regards, many business academics are facing various challenges to train graduates in big data analytics that require dynamic skills (technical as well business skills; computer programming, statistics, and operations research). Some universities have smartly integrated their business schools with computer science, statistics, mathematics, and engineering to provide such dynamic skills. Other schools are trying to hire multi-skilled academics, who have background in business operations as well in other technical areas (e.g., mathematics, statistics, data science and computing). However, finding such academics is a striking challenge for universities. The further challenge universities are facing is the lack of industrial collaboration with relevant firms (e.g. LinkedIn, Facebook, Amazon, eBay, Google, and other IT companies), which frequently use big data analytics for relationship innovation and can help students to engage in industrial projects.

Additionally, data analytics itself is a challenging domain. One has to be very ambitious to complete a degree in analytics without have a relevant background in mathematics, statistics, and computing. Many business students come from other qualitative disciplines, which does not only create a challenge for students but also for academics to build student fundamentals before students can digest real analytics. Such challenges question business school curriculum and require restructuring of educational policies that can be better intersected with contemporary data-andtechnology driven business operations for relationship innovation. 


\subsection{Limitations and future research}

This study is not without limitations. Firstly, though the framework has been established based on empirical data, no causal claims can be made as this is survey-based study. Secondly, the study is based on the selected agri-food partnerships, which may not reflective of other industries. Importantly, this research area, particularly the power of big data analytics, is still in its infancy. The underlying constructs might behave differently in other industries. However, there are still interesting insights for other industries or firms that are typified with similar characteristics. Finally, big data and analytics rapidly change and the timing of our study might affect the findings.

Future research could further support the findings based on in-depth case studies, which should particularly focus on big data and analytics that can help to make automated relationship management decisions. Research believes that data is being generated exponentially in modern business operations and this trend has thrown many challenges, including advanced analytics and machine learning techniques to handle them. The emerging applications of internet of things are further inundating contemporary business operations with complex data that is not only valuable for relationship innovation/performance dimensions but also for interdisciplinary research and development, rooted with business operations, computing, statistics, and mathematics. Consequently, these intersections provide many opportunities to integrate such cutting edge research that can make contemporary business operations/courses more innovative.

\section{References}

Ahammad, M. F., Tarba, S. Y., Liu, Y. and Glaister, K. W. (2016) Knowledge transfer and crossborder acquisition performance: The impact of cultural distance and employee retention. International Business Review, 25, 66-75.

Ahuja, G. (2000). The duality of collaboration: inducements and opportunities in the formation of interfirm linkages. Strategic Management Journal, 21, 317-343.

Akhtar, P. (2013) Determinants of coordination effectiveness of selected international agri-food supply chains: a structural equation modelling approach: a thesis presented in partial fulfilment of the requirements for the degree of Doctor of Philosophy in Logistics and Supply Chain Management, School of Engineering and Advanced Technology, Massey University, New Zealand. Akhtar, P., Tse, M., Khan, Z. and Rao-Nicholson, R. (2015) Data-driven and adaptive leadership contributing to sustainability of global agri-food supply chains connected with emerging markets. International Journal of Production Economics.

Antonakis, J., Bendahan, S., Jacquart, P. and Lalive, R. (2010) On making causal claims: A review and recommendations. The Leadership Quarterly, 21, 1086-1120. 
Aramyan, L. H., Lansink, A. G. O., Van Der Vorst, J. G. and Van Kooten, O. (2007) Performance measurement in agri-food supply chains: a case study. Supply Chain Management: An International Journal, 12, 304-315.

Baron, R. M. and Kenny, D. A. (1986) The moderator-mediator variable distinction in social psychological research: Conceptual, strategic, and statistical considerations. Journal of personality and social psychology, 51, 1173-1182.

Barton, D. and Court, D. (2012) Making advanced analytics work for you. Harvard Business Review, 90, 78-83.

Benton, W. and Maloni, M. (2005) The influence of power driven buyer/seller relationships on supply chain satisfaction. Journal of Operations Management, 23, 1-22.

Bidault, F. and Castello, A. (2009) Trust and creativity: understanding the role of trust in creativity-oriented joint developments. $R \& D$ Management, 39, 259-270.

Blackhurst, J., Dunn, K. S. and Craighead, C. W. (2011) An empirically derived framework of global supply resiliency. Journal of Business Logistics, 32, 374-391.

Brown, J. R., Lusch, R. F. and Nicholson, C. Y. (1996) Power and relationship commitment: their impact on marketing channel member performance. Journal of retailing, 71, 363-392.

Chen, H., Chiang, R. H. and Storey, V. C. (2012) Business Intelligence and Analytics: From Big Data to Big Impact. MIS Quarterly, 36, 1165-1188.

Chen, J., Zhao, X., Lewis, M. and Squire, B. (2015) A Multi-Method Investigation of Buyer Power and Supplier Motivation to Share Knowledge. Production and Operations Management.

Chen, L. G., Ding, D. and Ou, J. (2014) Power structure and profitability in assembly supply chains. Production and Operations Management, 23, 1599-1616.

Christopher, M. (2005) Logistics and supply chain management: creating value-added networks: Pearson education.

Clauss, T. and Spieth, P. (2016) Treat your suppliers right! Aligning strategic innovation orientation in captive supplier relationships with relational and transactional governance mechanisms. $R \& D$ Management.

Frey, M., Iraldo, F. and Testa, F. (2013) The determinants of innovation in green supply chains: evidence from an Italian sectoral study. $R \& D$ Management, 43, 352-364.

Frooman, J. (1999) Stakeholder influence strategies. Academy of Management Review, 24, 191-205. Hagedoorn, J., Kranenburg, H.V. and Osborn, R.N. (2003). Joint patenting amongst companies-exploring the effects of inter-firm R\&D partnering and experience. Managerial and Decision Economics, 24, 71-84.

Handley, S.M. and Benton, W.C. (2012). Mediated power and outsourcing relationships. Journal of Operations Management, 30, 253-267.

Hazen, B. T., Boone, C. A., Ezell, J. D. and Jones-Farmer, L. A. (2014) Data quality for data science, predictive analytics, and big data in supply chain management: An introduction to the problem and suggestions for research and applications. International Journal of Production Economics, 154, 72-80.

Hedgebeth, D. (2007) Data-driven decision making for the enterprise: an overview of business intelligence applications. VINE, 37, 414-420.

Hoole, R. (2005) Five ways to simplify your supply chain. Supply Chain Management: An International Journal, 10, 3-6.

Ireland, R. D. and Webb, J. W. (2007) A multi-theoretic perspective on trust and power in strategic supply chains. Journal of Operations Management, 25, 482-497.

Ke, W., Liu, H., Wei, K. K., Gu, J. and Chen, H. (2009) How do mediated and non-mediated power affect electronic supply chain management system adoption? The mediating effects of trust and institutional pressures. Decision Support Systems, 46, 839-851.

Keil, T., Maula, M., Schildt, H., Zahra, S.A. (2008). The effect of governance modes and relatedness of external business development activities on innovative performance. Strategic Management Journal, 29, 895-907.

Kline, R. B. (2011) Principles and practice of structural equation modeling: Guilford press. 
LaValle, S., Lesser, E., Shockley, R., Hopkins, M. S. and Kruschwitz, N. (2013) Big data, analytics and the path from insights to value. MIT Sloan Management Review, 21, 20-32.

Ledgard, S. F., Lieffering, M., Coup, D. and O'Brien, B. (2011) Carbon footprinting of New Zealand lamb from the perspective of an exporting nation. Animal frontiers, 1, 40-45.

Lin, R.-J., Chen, R.-H. and Kuan-Shun Chiu, K. (2010) Customer relationship management and innovation capability: an empirical study. Industrial Management \& Data Systems, 110, 111-133.

Makri, M., Hitt, M. A. and Lane, P. J. (2010) Complementary technologies, knowledge relatedness, and invention outcomes in high technology mergers and acquisitions. Strategic Management Journal, 31, 602-628.

Maloni, M. and Benton, W. C. (2000) Power influences in the supply chain. Journal of Business Logistics, 21, 49-74.

Maloni, M. J. and Brown, M. E. (2006) Corporate social responsibility in the supply chain: an application in the food industry. Journal of business ethics, 68, 35-52.

McAfee, A. and Brynjolfsson, E. (2012) Big Data:The management revolution. Harvard business review, 90, 61-67.

McAfee, A., Brynjolfsson, E., Davenport, T. H., Patil, D. and Barton, D. (2012) Big data. The management revolution. Harvard Bus Rev, 90, 61-67.

Narasimhan, R., Nair, A., Griffith, D. A., Arlbjørn, J. S. and Bendoly, E. (2009) Lock-in situations in supply chains: A social exchange theoretic study of sourcing arrangements in buyer-supplier relationships. Journal of Operations Management, 27, 374-389.

Nicolopoulou, K., Karataş-Özkan, M., Vas, C. and Nouman, M. (2016) An incubation perspective on social innovation: the London Hub-a social incubator. $R \& D$ Management.

Nyaga, G. N., Whipple, J. M. and Lynch, D. F. (2010) Examining supply chain relationships: do buyer and supplier perspectives on collaborative relationships differ? Journal of Operations Management, 28, 101-114.

Ollila, S. and Yström, A. (2016) An investigation into the roles of open innovation collaboration managers. $R \& D$ Management.

Patnayakuni, R., Rai, A. and Seth, N. (2006) Relational antecedents of information flow integration for supply chain coordination. Journal of Management Information Systems, 23, 13-49.

Phillips, W., Lamming, R., Bessant, J. and Noke, H. (2006) Discontinuous innovation and supply relationships: strategic dalliances. $R \& D$ Management, 36, 451-461.

Podsakoff, P. M., MacKenzie, S. B., Lee, J.-Y. and Podsakoff, N. P. (2003) Common method biases in behavioral research: a critical review of the literature and recommended remedies. Journal of applied psychology, 88, 879-903.

Preacher, K. J. and Hayes, A. F. (2008) Asymptotic and resampling strategies for assessing and comparing indirect effects in multiple mediator models. Behavior research methods, 40, 879-891.

Pullman, M. E., Maloni, M. J. and Carter, C. R. (2009) Food for thought: social versus environmental sustainability practices and performance outcomes. Journal of supply chain management, 45, 38-54.

Puranam, P., Singh, H. and Zollo, M. (2006) Organizing for innovation: Managing the coordination-autonomy dilemma in technology acquisitions. Academy of Management Journal, 49, 263-280.

Schewe, R. (2011) Two wrongs don't make a right: state and private organic certification in New Zealand dairy. Environment and Planning, 43, 1421-1437.

Sekaran, U. (2000) Research methods for business: A skill-building approach: John Wiley \& Sons.

Sharma, S. and Henriques, I. (2005) Stakeholder influences on sustainability practices in the Canadian forest products industry. Strategic Management Journal, 26, 159-180.

Sobel. (1982) Asymptotic confidence intervals for indirect effects in structural equation models. In: Leinhardt, I. S., ed. Sociological Methodology 1982. San Francisco, 290-312.

Tachizawa, E. M. and Wong, C. Y. (2015) The Performance of Green Supply Chain Management Governance Mechanisms: A Supply Network and Complexity Perspective. Journal of supply chain management. 
Terpend, R. and Ashenbaum, B. (2012) The intersection of power, trust and supplier network size: Implications for supplier performance. Journal of supply chain management, 48, 52-77.

Waller, M. A. and Fawcett, S. E. (2013) Data science, predictive analytics, and big data: a revolution that will transform supply chain design and management. Journal of Business Logistics, 34, 77-84.

Wang, G., Gunasekaran, A., Ngai, E. W. and Papadopoulos, T. (2016) Big data analytics in logistics and supply chain management: Certain investigations for research and applications. International Journal of Production Economics, 176, 98-110.

Weck, M. and Blomqvist, K., 2008. The role of inter-organizational relationships in the development of patents: A knowledge-based approach. Research Policy, 37, 1329-1336.

Xue, W., Demirag, O. C. and Niu, B. (2014) Supply chain performance and consumer surplus under alternative structures of channel dominance. European Journal of Operational Research, 239, 130145.

Zhu, Q., Crotty, J. and Sarkis, J. (2008) A cross-country empirical comparison of environmental supply chain management practices in the automotive industry. Asian Business \& Management, 7, 467-488.

\section{Appendix}

\begin{tabular}{|c|c|c|}
\hline Constructs & Brief items description & Codes \\
\hline \multirow[t]{4}{*}{$\begin{array}{l}\text { Mediated Powers: } \\
\text { Coercive (COR) }\end{array}$} & $\begin{array}{l}\text { 1. Main SC partners' punish (e.g., profit } \\
\text { reduction) us if we don't fulfill their } \\
\text { expectations }\end{array}$ & COR1 \\
\hline & $\begin{array}{l}\text { 2. They get back to us if we don't do as they } \\
\text { ask }\end{array}$ & COR2 \\
\hline & $\begin{array}{l}\text { 3. They withdraw from our services if we are } \\
\text { not consistent }\end{array}$ & COR3 \\
\hline & $\begin{array}{l}\text { 4. They often make it difficult if we don't } \\
\text { agree with them }\end{array}$ & COR4 \\
\hline \multirow[t]{5}{*}{ Manipulative (MAN) } & $\begin{array}{l}\text { 1. Main SC partners sometimes lie to protect } \\
\text { their interest }\end{array}$ & MAN1 \\
\hline & $\begin{array}{l}\text { 2. Complete honesty does not pay when } \\
\text { dealing with main SC partners }\end{array}$ & MAN2 \\
\hline & $\begin{array}{l}\text { 3. They exaggerate their needs for getting } \\
\text { things done }\end{array}$ & MAN3 \\
\hline & $\begin{array}{l}\text { 4. They often alter the facts to get what they } \\
\text { need }\end{array}$ & MAN4 \\
\hline & $\begin{array}{l}\text { 5. They sometimes manipulate the facts for } \\
\text { their interests }\end{array}$ & MAN5 \\
\hline $\begin{array}{l}\text { Non-mediated } \\
\text { Powers: }\end{array}$ & $\begin{array}{l}\text { 1. We trust main SC partners' expertise that } \\
\text { provide us analytical insights }\end{array}$ & EXP1 \\
\hline \multirow[t]{3}{*}{ Expert (EXP) } & $\begin{array}{l}\text { 2. They often provide good technical } \\
\text { suggestions for mutual benefits }\end{array}$ & EXP2 \\
\hline & $\begin{array}{l}\text { 3. They actively share their experiences with } \\
\text { other SC partners }\end{array}$ & EXP3 \\
\hline & $\begin{array}{l}\text { 4. Main SC partners often provide needed } \\
\text { technical knowledge }\end{array}$ & EXP4 \\
\hline
\end{tabular}


1. We are proud to be associated with main SC partners because of the way they run their SC operations

2. Main SC partners and we have similar feelings about the way SC operations should be run

3. We are identified with our main SC partners

4. Working with main SC partners gives us a feeling of pride

5. We often do things together as we are proudly associated with each others

Power of Big Data Analytics (PBDA):

\section{Relationship innovation: Using trust for relationship innovation}

Data, analytics and information sharing for relationship innovation
1. Vehicle tracking data (being part of the power of big data analytics) is not explored to achieve relationship innovation $(*)$

2. The power of big data analytics (e.g., analytics produced from large volume of data, terabytes) help us to improve relationship innovation

3. Click-stream analytics assist us to understand customers' purchasing behavior

4. Our social media analysts constantly provide PBDA4 feedback on online customer reviews

5. Real time analytics is our main strategy to PBDA5 use the power of big data analytics for relationship innovation

6. We also utilize text analytics as the power of big data to improve our service quality

7. Our marketing department frequently uses the power of big data analytics for our market growth

8. Smart devices are used for real-time analytics, being part of our power of big data analytics

1. We have built trusted innovative

TRT1 relationships

2. Our relationships are based on mutual trust TRT2

3. We trust sharing best relationship practices TRT3

4. Trust is the key contributor for our TRT4 relationship innovation

5. Trust helps us in joint decision making for TRT5 better relationship innovation

6. Trust is very important for relationship TRT6 innovation

1. Data sharing is our important strategy for DAIS 1 relationship innovation

2. We inform our collaborative partners in DAIS 2 advance of changing needs

3. It is expected that any information which DAIS 3 
might help to build relationship innovation

is shared among collaborative partners

4. It is encouraged to share data and information that can make contributions

5. We have joint data and information platforms that can be accessed by our collaborative partners

6. Joint decision making for better relationship DAIS 6 management is not practiced (*)

7. Our teams share data and information to $\quad$ DAIS 7 resolve relationship problems

8. Our analytical teams provide insights to DAIS 8 solve operational problems

9. We have comprehensive analyticalDAIS 9 integrations with collaborative partners

10. Our analysts share specific information (e.g., DAIS 10 capacity loads, returns) with our collaborative partners

11. Our analysts share customers' reviews for building relationship innovation

12. Large datasets (e.g., terabytes) are used for building better relationship innovation

13. Use of big data analytics is our main focus to build relationship innovation

Using satisfaction for relationship innovation
1. Overall, we have satisfactory relationships with our collaborative partners

2. We have long term relationships with our collaborative partners

3. Collaborative partners do not make any demands that can hurt our relationship innovation
SAT1

SAT 2

SAT 3

*Items reversed. The used items were adjusted to the purpose of this study 


\section{Author biographies}

Pervaiz Akhtar is a Senior Lecturer (Associate Professor), Program Leader of Logistics \& SCM, and Program Director of MSc Analytics/Data Science Division at University of Hull Business School, UK. He previously worked as a Research Officer/Lecturer at Massey University, New Zealand. Pervaiz has also worked for (or with) non-profit and for-profit organizations (UNICEF, JCCP, Oxfam, MSF, Islamic Relief, Red Cross, high government officials, dairy industry, FMCG companies like Unilever and Reckitt Benckiser) at senior levels (operations/logistics/project director and manager). His research has appeared in top ranked journals such as the International Journal of Production Economics, Supply Chain Management: An International Journal, IJHRM, R\&D Management, among others. His professional interests are mainly in network analysis, big data analytics, IoTs, ICT, optimization, simulation, ANP applications, innovation and innovative research methods. He can be reached at pervaiz.akhtar@hull.ac.uk.

Zaheer Khan is a Reader (Associate Professor) at Kent Business School, the University of Kent. He gained his $\mathrm{PhD}$ in International Business at the University of Birmingham, UK. Prior to entering academia, he worked as a Consultant for Capgemini Ernst \& Young, USA. His research interests are international knowledge transfer, capability development, automotive industry, and cross-border alliances. He has published in the Journal of International Business Studies, Global Strategy Journal, International Business Review, International Marketing Review, and Industrial Marketing Management, among others. He can be contacted at khan.zaheer@gmail.com.

Rekha Rao-Nicholson is a Senior Lecturer in International Business at Newcastle University London. Her research interests are strategy and business in emerging economies, growth of MNCs from emerging economies, and the economics of innovation. She has published in Research Policy, International Business Review, Asia Pacific Journal of Management, Thunderbird International Business Review, among others. She can be contacted at rekha.nicholson@ newcastle.ac.uk.

Minhao Zhang is a PhD candidate in The York Management School at the University of York. His research interest includes managerial risk perception, supply chain risk management, quality management and the social media analytics. He has published in Supply Chain Management: An International Journal and Industrial Management and Data System. He can be contacted at minhao.zhang@york.ac.uk. 